\title{
The Influence of Javanese Culture on Hadhrami Community in Coastal Society of Semarang
}

\author{
Rabith Jihan Amaruli ${ }^{1}$, Singgih Tri Sulistiyono, Dewi Yuliati, Endang Susilowati \\ Doctoral Program of History, Faculty of Humanities, Universitas Diponegoro, Semarang, Indonesia
}

\begin{abstract}
From the end of the 19th century to the beginning of the 20th century, Hadhrami immigrants had formed colonies in Semarang, the north coast of Java. They inhabited Arab areas such as Kampung Melayu and Kampung Kauman. In the 1970s to 1980s, due to ecological change and economic problems, some of them left these areas and moved to other areas in Semarang. It caused cultural encounters between Hadhrami and Javanese to become much more intensive. Through literature studies, observations, and interviews, this study aims to identify the influence of Javanese culture on the Hadhrami community in contemporary Semarang. In the process, cultural encounters emerged between hybrid generations which created hybrid cultures. It can be seen by language, fashion, and food. In this context, the hybridity is caused by the history and character of Semarang as a coastal society that is fluid and cosmopolitan.
\end{abstract}

\section{Introduction}

This This article examines the influence of Javanese culture on the Hadhrami community in Semarang. As a city on the north coast of Java, Semarang has been one of the important ports in the Java Sea region since colonial times and Batavia, Gresik and Surabaya. This caused Semarang to become one of the shipping and trade networks centres in the archipelago, even globally [1]. Semarang's important position has made it one of the destinations for the Hadhrami people to come to look for a new life, far from their homeland in Hadhramaut, South Yemen. The influx of Hadhrami migrants increased significantly since the development of steamship technology and the opening of the Suez Canal in 1869 [2]. In the late 19th to early 20th centuries, Semarang saw a rise in colonists, from 509 in 1860 to 916 in 1900. Although the number dropped in 1905 to 854 people, Semarang remained one of the 10 largest Arab colonies in the Dutch East Indies [3]. In Semarang, they live in two main areas, Kampung Melayu and Kampung Kauman. In Semarang, there was no such thing as Kampung Arab. There, Arabs lived together with other groups of migrants, such as Gujarati, Indian and Chinese, and Javanese natives [4]. However, from the 1970s to the 1980 s, some of them moved to other areas in Semarang for ecological and economic reasons, while others remained in the area.

These conditions have provided a context for the cultural encounter between the Hadhrami community and Javanese culture. Cultural encounter has become an increasingly

*Corresponding author: riamaruli@live.undip.ac.id 
popular term used to describe the dynamics of the flow of cultural formation as a result of interactions between groups and individuals across cultural boundaries [5]. Cultural encounters can also be understood as a product of cross-cultural communication between one community and another, which forms the basis for social integration. This is possible because the connection by sea has conditioned the occurrence of cross-cultural communication through both shipping and trade channels. The geographical conditions of Semarang, which is located on the coast, have made this activity possible. This is because coastal areas contain dynamics that create unity and relations between humans and nations through transportation, trade, and cultural encounters. In turn, this cultural meeting will produce a hybrid culture. Hybrid culture or hybridity mostly refers to culture, but still maintains the meaning related to three aspects, such as race, language, and ethnicity, which are interconnected [6]. In the context of Hadhrami community, the cultural encounter and its hybrid cultural result from the diaspora.

Tdiaspora process also shows a reciprocal relationship. On the one hand, this cultural encounter has influenced the cultural form of the Hadhrami people in a new place, in this context- Semarang. On the other hand, Indonesian culture has also influenced the Hadhrami culture in their area of origin, Hadhramaut. The impact of this relationship is a new mixed cultural form, which can be seen in language, clothing, food, and architecture [7]. This article adopts these findings from a different perspective. However, the Hadhrami diaspora to various regions has created new relationships. Migrants in all countries tend to maintain their identity in the new homeland for most aspects of their lives. On the one hand, the Hadhrami people influence the local community, while on the other hand, they are also influenced by the local community's culture. Several studies on the Hadhrami people have been carried out and discuss how the original identity of the Hadhrami migrants is maintained from generation to generation (see Jonge and Kaptein 2002 [8]; Abushouk and Ibrahim 2009 [9]; and Manger 2010 [10]).

Based on the description above, this article wants to confirm the following two main things. First, how did the cultural encounters between Hadhrami and Javanese culture take place? To answer this, it is necessary to look at the Hadhrami diaspora and their identity struggle in their new homeland, Semarang. Second, as a result of these cultural encounters, what forms of hybrid culture can be found. To answer this, it will be seen through the three forms of hybrid culture that are most easily observed, namely language, fashion, and food.

\section{Method}

Following the historical method, this article was prepared by using literature study, observation, and interviews [11] [12]. Literature study was conducted by examining sources in the form of books, articles, and newspapers both in printed form or online. Observations focused on the three main aspects that were most easily observed, such as language, fashion, and food. These three things will be seen in the life of the Hadhrami family such as Alaydrus, As-Segaf, Al-Jufri, Al-Habsyi, Al-Munawar, bin Smith, and Sungkar in two main locations, namely Kampung Melayu and Kampung Kauman. During observation, interviews about their history, role, and social formation are also conducted through oral history interviews [13]. The information obtained from those methods are then classified, interpreted, and presented in an article following the predetermined framework [14]. 


\section{Result and Discussion}

\subsection{Hadhrami Community in Semarang: Diaspora, Marriage Pattern, and Cultural Encounter}

The Hadhrami are an ethnoreligious community who have long migrated from their homeland in Hadhramaut, South Yemen, to various coastal areas that border the Indian Ocean, such as the eastern coast of Africa, India and Southeast Asia. Although the early arrival of Hadhrami in several places on the coast of the Indian Ocean can be ascertained, the migration of Hadhrami to Southeast Asia in large numbers did not occur until the end of the 19th century, especially after the discovery of steamships and the opening of the Suez Canal in 1869 [15]. According to Berg, it was only in the 19th century that the significance of the Hadhrami's role had a striking influence on the political future of the natives [4]. In the 19th century, the coast of Java was under the control of the Dutch colonial government, including the places where Hadhrami people lived and established settlements. According to their place of residence in Java, the Arab-Hadhrami can be mapped in two. First, those who live in Arab villages are very strict about maintaining their customs and the blood of their descendants. Second, namely, those who lived mixed with the natives from the beginning and had long been assimilating. Those who assimilate have long been considered natives. In the census of the Dutch East Indies colonial government, most of the latter were classified as indigenous [4] [16].

In 1930, there were 110,000 Hadhrami migrants and 70,000 who lived in the Indies [17]. In the 19th century, the Hadhrami migrated without sufficient financial capital. They started careers as small traders, then developed larger businesses. They also invested in real estate, and some of them became very successful entrepreneurs [18]. At the end of the 19th century, in Semarang, for example, there were 14 companies owned by Hadhrami entrepreneurs. This made Semarang an important trading centre alongside Surabaya, Batavia, and Singapore [18] [4]. As a result, the Hadhrami diaspora is often characterised as a trade or entrepreneurial diaspora, although its existence is often forgotten compared to the Chinese or Indian diaspora.

In Semarang, Hadhrami colonies are thought to have existed since before the 19th century. However, in 1819, it seems that the number of Hadhrami in Semarang was large enough to be led by a colony chief. Between 1840 and 1855, some Hadhrami people in Semarang began to accumulate enormous wealth and capital, which their descendants could still enjoy. However, many of them also fell into poverty, while some rose again by marrying wealthy indigenous people. In the 1860 s to 1870 s, the colony declined slightly. However, a few years later, the number of Hadhrami immigrants to the region increased. In Semarang, the Hadhrami people did not have their territory. They settled in Kampung Melayu, where Chinese and Javanese lived. A mosque was built for daily worship by the Hadhrami with a typical tower architecture [4] [19]. At the end of the 19th century, an Arab colony in Semarang also seemed to be settled by other immigrants from Bengal. This is evidenced by the appointment of an Arab Captain who was also the leader of the Bengal colony. In 1892, for example, the Arab and Bengal Captains in Semarang were led by Sayyid Mohammad bin Ahmad Al-Jufri, assisted by his colleague, Sayyid Ahmad bin Salim Moetahar. However, in contrast to the more strategic first position, this second-person position was only a titular, or non-functional position [20]. 
In general, only men migrated without their wives and sisters. When they arrived in the archipelago, they later married women from several local ethnicities. This means, almost all descendants of Hadhrami at this time have the status of muwallad or peranakan (mixedparentage) and not wulaytis or totok (pure-blooded) [21]. Despite having peranakan status, they are still considered part of the Hadhrami community, recognising patrilineal lineage. However, being part of the lineage cannot guarantee their Hadhrami identity. Some second or third generation Hadhrami have lost their Arabic identity altogether [4]. That is why the marriage pattern of the Hadhrami people emphasises endogamy, which is characterised by a tendency for muwallad to marry another muwallad [22].

The The Hadhrami community is divided into social strata. They are divided horizontally, namely sāda, masyayikh, and qabail, and one group outside the three, masakin [23]. Endogamy is especially emphasized among the Hadhrami people who call themselves descendants of the Prophet Muhammad. This group is called sāda (sing, sayyid), which means lord or noble. They are called the descendants of the nobility and became an elite religious group in Hadhramaut. Therefore, sāda is often considered the first and highest group in social stratification in Hadhramaut. The second group is the mashayikh (sing. Sheikh). As with sāda, the mashayikh group has a particular position in the religious domain. The third group is the qaba'il (sing, qabili) or people of the tribe who take up arms. The fourth group is the urban community in general, which consists of masakin and hadhar/qarwan. This group consisted of traders and artisans who had no genealogical claims and religious authority. The fifth group is dhuafa (sing, dha'if), which means weak. This group consists of farmers and construction workers. The sixth group is the 'abid (slaves), which consists of the sultanate's servants, workers, and soldiers. The seventh group is the subiyan, which is a group of workers or slaves from Ethiopia. The latter group was not thought to be among those that came to the archipelago [24].

Despite being outside their native land, the Hadhrami appear to maintain endogamous mating patterns within their respective groups, particularly sāda. Sayyid and sharifa (title for women) are expected to marry within the sāda community. A sharifa is not allowed to marry a non-sayyid. This concept is called kafa'a, which is usually translated as "equality". Kafa' $a$ is still upheld by the majority of Hadhrami, both in the Hadhramaut and in the archipelago, and of course, it remains a limitation in the exercise of women's agency.

In contrast to women, kafa' $a$ was not strictly applied to Hadhrami men, especially Hadhrami men in the diaspora who were given the option of taking wives from outside society [25]. The pattern of Hadhrami marriage, which was ideologically based on the principle of kafa' $a$, was essential to build a Hadhrami community in a new place. Mating based on patrilineal and endogamy patterns would preserve their lineage [25] [15]. The title of the father would be passed down to their children, both men and women. Apart from internal factors, the endogamous marriage pattern was also influenced by external factors, including the Dutch East Indies colonial policy, which obliged them to live in the "Arab areas" or Arab villages. In addition, their special status in colonial society as Vreemde Oosterlingen (Foreign Easterners) led to social segregation between the Hadhrami community and Javanese natives. These regulations were gradually introduced in the $1850 \mathrm{~s}$ and only abolished in 1919 [2].

However, colonial heritage "Arab villages" are still well known in many cities in Java, such as Surabaya, Semarang, and Pekalongan. There, the ideal marriage pattern according to the kafa' $a$ principle is still being practiced, and at the same time, being opposed. At the beginning of the 20th century, this contradiction became increasingly prominent and gave rise to two main groups in the Hadhrami community - Irsyadi and Alawi. Generally, the Irsyadi group is affiliated with the Al-Irsyad organization founded by Sheikh Ahmad Surkati and carries the spirit of Islamic reform. Meanwhile, Alawites are a group affiliated with the Rabithah Alawiyah organization. Suppose the Irsyadi group is a non- 
sayyid representation that simultaneously carries an anti-sayyid spirit. In that case, the Alawi camp is a sayyid group that tries to defend sayyid values and principles. One of the principles that are the point of contention is kafa'a. According to Irsyadi, a syarifa may marry any man they choose [26].

The Hadhrami community in Semarang gained momentum when the clash between the two groups, Irsyadi vs Alawi, turned into a new form of solidarity through the ArabIndonesian Association (PAI) in 1934, initiated by A.R. Baswedan. At that time, Semarang was the place for A.R. Baswedan to campaign for his ideas on the integration and emancipation of Arab-Indonesians. Ultimately, he succeeded in attracting the interest of 40 well-known Hadhrami from various social classes on October 4-5, 1934. They met and gathered at Said Bahilul's house in Kampung Melayu, Semarang. Among them were entrepreneurs, traders, formal and informal leaders. The Batavian Arab breed was represented by Hasan Argoebi, an Arab captain, member of the central board of Al-Irsyad, and son-inlaw of wealthy businessman Oemar Mangoes, and Muhammad Abu Bakar Alatas, son of chairman Rabithah Alawiyah and one of the largest real estate owners in Kwitang. The representative from Solo was Ahmad Bahaswan, one of the founders of the first Dutch-Arabic school. Representatives from Semarang are Idrus Al-Jufri, Rabithah Alawiyah and an Arab captain and Nuh Al-Kaff from the weekly Pewarta Arab. The Pekalongan representative was Husein Al-Kadri, from the Arabic language monthly media, As-Syifa', while the representative from Surabaya was Salim Maskati [27].

The idea of integration led to the Arab Youth Pledge in 1934. It continued to be propagated by PAI, whose name was later changed to the Arab-Indonesian Party (also abbreviated as PAI). In December 1943, together with ethnic Chinese, Hadhrami peranakan were again allowed to travel without permission. In July 1944, the ethnic Hadhrami were no longer classified as foreigners. However, migrant descendants from other groups still did not have the same status as Indonesians [27]. However, this changed after Japan suffered defeat in 1945. The Hadhrami was reclassified as a distinct population group (neither native nor foreign), along with Chinese and Europeans, until December 27, 1951. Although many were disappointed, most Hadhramis accepted this. As second-class citizens, they again experienced various difficulties in carrying out their profession, such as not being eligible to obtain financial support available to indigenous entrepreneurs, becoming members of cooperatives, or buying land. Even the Hadhrami, who were civil servants, had to stand in line behind the natives. Both the rulers and the natives continued to view and treat the Hadhrami as foreigners [27].

The number of Hadhrami in Semarang was not precise after Indonesia's independence. In the 1970 s and 1980 s, due to ecological and economic reasons, some of the Hadhrami families decided to move from their old villages to new settlements, both inside and outside Semarang. Tidal floods that inundated the Kampung Melayu area forced villagers to abandon their houses and move to new areas, prompting the establishment of new settlements in Semarang, such as Wologito, Sendangmulyo, and Banyumanik [28]. Meanwhile, for reasons of preaching and better livelihoods, some decided to move out of town. Habib Hasan Bunumay, for example, chose to move to Kudus, a city east of Semarang, and build a religious congregation there [29]. Some also moved to Jepara and Karimunjawa, such as Sayyid Abdurrahman Al-Hamid. In the 1960s, after leaving madrasa, he worked as a labourer for a Chinese merchant. When the Chinese merchant moved to Karimunjawa in 1963, he decided to move and live on that island. There, he married and had several children. Far from Semarang, he also decided that his daughter should marry a Javanese Muslim (nonsayyid) man, even though the daughter has a sharifa status [30].

The religious elite of the Hadhrami still maintains their traditions by holding dhikr and salawat congregations. One of them was Habib Zen Al-Jufri. He was born in Jalan Petek, North Semarang, in 1911. He was one of the four children of Habib Ali bin Ahmad bin Umar 
Al-Jufri. His ancestor, Habib Umar Al-Jufri, came from Taris, a small town between Seiwun and Syibam. He came to Semarang with his young son, Ahmad. Habib Umar then traded and engaged in Islamic preaching in Semarang. Then, he married his son, Ahmad, to the daughter of the governor of Batang Regency, Central Java. His grandfather then built a house on Jalan Petek, which was classified as luxurious and ample. Ahmad was a successful trader, leaving behind many possessions. Little Zen Al-Jufri attended madrasa in Semarang, then went to Madrasah Shama'il Al-Huda in Pekalongan. In his teens, he studied in Hadhramaut in Taris, and one of his teachers was Habib Idrus Al-Jufri, Palu, the founder of the Al-Khairat College. At Hadhramaut, he only studied for three months. Then, he was invited to return to Indonesia by Habib Idrus Al-Jufri. In Indonesia, Habib Zen Al-Jufri continued his studies with many teachers, especially in Jakarta. Among them was Habib Ali bin Abdurrahman Al-Habsyi in Kwitang, but quite regularly he studied with Habib Abdurrahman Assegaf. While in Pekalongan, he studied with Habib Ahmad bin Abdullah bin Talib Alatas. In the 1950s, he returned to Semarang and built his congregation at Jalan Petek 55. He died in December 1992 and was buried in the Bergota Cemetery, Semarang [31]. The Habib Zein religious study group was continued by Habib Abu Bakar Al-Atas. Every fourth Wednesday, people gather to study religion at his house at Jalan Petek, Dadapsari Village [32].

Some of the Hadhrami families who remained in Kampung Melayu and Kampung Kauman maintained their Hadhrami traditions by making new adaptations. Although mixed marriages can be found, the majority of Hadhrami people still practised endogamy. This was especially true for families with sayyid backgrounds. The practice of mixed marriages in families with sayyid backgrounds usually applied to men. They could marry into nonsayyid Hadhrami families, such as Sungkar and Harhara [29], or Javanese women [33]. In sayyid families, a sharifa sometimes could not determine their partner and the parents would look for a prospective son-in-law from a sayyid family. The latter come from various family networks and their business acquaintances. Javanese traditional practices were apparent in the transitional rites for families with mixed marriages, with a few adaptations. For example, the ritual of mitoni (derived from the Javanese language, pitu or seven, which means ceremony to commemorate the seven months of pregnancy) becomes ngapati (derived from the Javanese language papat or four, which means the ceremony to commemorate the four months of pregnancy). For them, ngapati is considered more religiously based because it follows the Islamic concept about ruh [34]. However, there was also a Hadhrami in Semarang, who changed his name from Salim to Salimin not to be treated differently from the Javanese [35].

Apart from the births, the Hadhrami family funeral rites are of particular interest. Funeral ceremonies are usually distinguished based on the religious orientation of each family. In the Hadhrami families oriented towards modernist Islam, the funeral ceremony is more straightforward and without a ritual. However, in traditionalist Islam-oriented Hadhrami families, this is usually followed by recitation of the talqin of the deceased and tahlil followed by a seven-day, 40-day commemoration and haul (anniversary of death). For example, the 22nd haul akbar (big anniversary of the death) of Habib Abdurrahman bin Zein Al-Jufri, one of the Hadhrami figures in Semarang in 2018, marked this existence group in the Semarang community [36]. Many Hadhrami families are buried in the same cemetery as their Javanese brothers. However, some prominent Hadhrami families, such as the As-Segaf and Al-Jufri families, have particular burial grounds in Bergota cemetery, Semarang (See Fig. 1). 


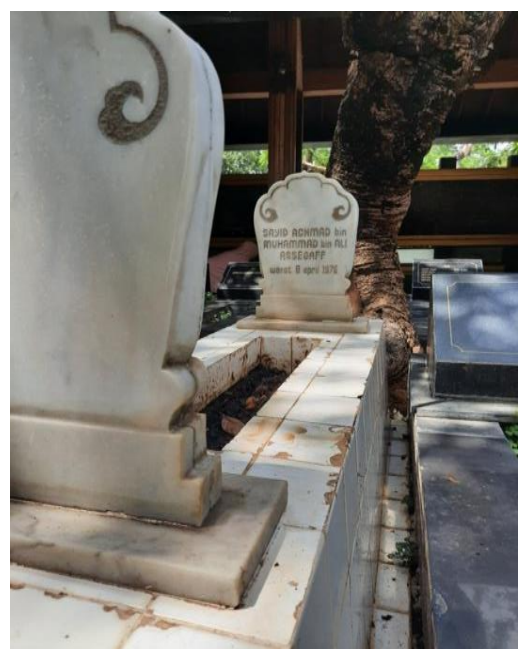

Figure 1. Photo of the tomb of Habib Achmad bin Muhammad bin Ali As-Segaf (died 8 April 1976), a figure of the Semarang Hadhrami in the cemetery of the As-Segaf Family, Bergota Semarang (Source: Photo by Rabith Jihan Amaruli) [37].

Like their predecessors, there were hardly any Hadhrami in Semarang who were not interested in trading. They run businesses by opening book stores and shops selling perfumes, hajj souvenirs, glasses and electronic goods, and clothing factories. Their longstanding network has strengthened their interest in the business. Along with the renovation of the Kauman Village area, several new shops began to open. In the 1990s to 2000s, several prominent Hadhrami figures in Semarang began to develop their businesses in publishing, hajj travel, and restaurants offering Middle Eastern dishes. An essential figure in this category is Hasan Thoha Al-Munawar. In the 1970s, he founded the PT Thoha Putra publishing company. His success as an entrepreneur and philanthropist led him to establish educational institutions and hospitals under the auspices of the Sultan Agung Waqf Foundation (YBWSA) in 2013 [38]. Meanwhile, several years earlier, in 2000, Hasan Thoha AlMunawar and other Hadhrami figures in Semarang, such as Hasan Al-Jufri, founded the Hidayatullah Islamic Senior High School (SMAIH). This institution was an expansion from the Abul Yatama Foundation, founded in 1984 and oversees other educational institutions, including pre-school, Quranic study school, Hidayatullah Islamic Elementary School, and Hidayatullah Islamic Junior High School (SDIH) [39]. Meanwhile, other Hadhrami, when not involved in business or trade as their main livelihoods, work as doctors, teachers, academics, and civil servants.

\subsection{Cultural Encounter and Hybridity: Language, Fashion, and Food}

In The discussion above has been described how the Hadhrami diaspora in Semarang has gone through a long process. This process provides conditions for cultural encounters, which in turn produce a cultural hybrid. In this context, although endogamous marriage still prevails among the Hadhrami, it has also made way for new cultural forms. As it is a hybrid culture, on the one hand, they try to maintain their Hadhrami identity, while on the other hand, they naturally make various adaptations. For example, from the marriages, although the sayyid married Javanese women, they did not appear to have married their syarifa to the non-sayyid group. This relationship helps the process of integrating the sayyid with the local people and at the same time maintaining their genealogical identity. By doing so, they succeeded in forming a "fluid" identity based on genealogy rather than more dense forms of 
identity such as ethnicity and race [40]. Furthermore, as a coastal city, the egalitarian and "fluid" character of Semarangan Javanese culture also influences the dynamic aspects of their culture. To prove this, three main aspects are of interest, language, fashion, and food. These three things are described as follows.

\subsubsection{Language}

Since colonial times, the Hadhrami family in Semarang married native women or their compatriots' daughters, who never left Semarang. As a result, they are similar to indigenous women, both language, culture and customs. In some families, there are even men married to Chinese and European ethnicities, so the language of conversation in the Hadhrami family homes is not Arabic, but rather Malay (read: Indonesian) and Javanese. They also use those languages with their children. Even though some learn Arabic and read the Koran, their daily spoken language is still Indonesian and Javanese. However, just as the peranakan Chinese have a distinctive accent, the Hadhrami people in Semarang also have their accent. Although administratively, Semarang is included in the Central Java region, where the Javanese Surakarta language is the dominant language, anthropologically, as a coastal community, Semarang has its own distinctive dialect.

Nowadays, even though the level of language integration is relatively high, Arabic terms are often found and spoken by them, such as ana (me) and ente (you). In some conversations, the word ajib to praise something or yahanu is often found when doubting something. In addition, the term harem denote a woman or wife and zuwaj (marry) are also often spoken by some Hadhrami people in Semarang. An example is seen in table 1:

Table 1. Use of Arabic Terms in Daily Conversation of Semarang Hadhrami Arabs.

\begin{tabular}{|l|l|}
\hline \multicolumn{1}{|c|}{ Indonesiaan Language } & \multicolumn{1}{c|}{$\begin{array}{c}\text { Indonesian Language with Hadhrami } \\
\text { Semarangan dialect }\end{array}$} \\
\hline Kapan kamu berangkat ke Solo? & Kapan ente mo' berangkat ke Solo? \\
\hline Besok, saya berencana berangkat ke Solo & Besok, ana rencana mo' berangkat ke Solo \\
\hline $\begin{array}{l}\text { Kalau begitu, tolong besok saya sekalian } \\
\text { dibelikan roti ka'ak di toko Paman Ahmad? }\end{array}$ & $\begin{array}{l}\text { Kalo gitu, tulung mbesok ana sekalian dibelikken } \\
\text { roti ka'ak di toko Ami Ahmad? }\end{array}$ \\
\hline $\begin{array}{l}\text { Wah hebat betul Paman Ahmad, bisa menjadi } \\
\text { pedagang sukses. Apa rahasianya ya? }\end{array}$ & $\begin{array}{l}\text { Wah ncen ajib Ami Ahmad, isa jadi pedagang } \\
\text { sukses. Opo rahasiane ya? }\end{array}$ \\
\hline $\begin{array}{l}\text { Wah, kamu pura-pura. Rahasianya tentu bekerja } \\
\text { keras. }\end{array}$ & Wah, yahanu ente. Rahasiane kerja keras to yo. \\
\hline $\begin{array}{l}\text { Kalau sukses begitu kok tidak mencari istri lalu } \\
\text { menikah ya? }\end{array}$ & $\begin{array}{l}\text { Nek sukses gitu kok ndak cari harem lalu zuwaj } \\
\text { aja ya? }\end{array}$ \\
\hline
\end{tabular}

Beside Indonesian, they also speak the Javanese language of Semarangan dialect with special notes and terms, such as the use of the $i k$ and owk suffix, for example A: Hawane panas biyanget ik (Cuacanya panas sekali/ The weather is very hot); B: He'e owk (Iya yal So true). They also use mas for brother and mbak for sister, for example A: Mah, ini ada mas Jihan, mbawakken nasi kebuli/Mom, Jihan is here bringing you a nasi kebuli) B: Oh yo mas, masukko. Dudukko sik/ Okay, come in. Please sit down). The way to speak in a coastal style that is assertive, egalitarian, and straightforward, greatly influences the communication patterns of the Hadhrami in Semarang, for example kowe kie yaknah (you are so nonsense), or Ncen kowe-kowe kie yaknah beh (Indeed, all of you guys are nonsense). However, there are also Hadhrami who can speak Javanese krama fluently. The Hadhrami in this category usually have a large family background from Solo, Central Java. The use of sebeh for father and semeh for mother is also found. Even so, at home, the mention of father is still abah, while mother is still mamah or umik. 


\subsubsection{Fashion}

Since Since colonial times, the Hadhrami have been easily distinguished by the clothing (fashion), such as the jubah and gamis. Jubah is a flowing buttonless cloth. Religious leaders usually wear a jubah, complete with Imamah and a turban. The robe (gamis) is a loose cloth to the ankles and under the robe, they usually wear a sirwal (short pants) or sruwal in Javanese. Many Hadhrami people wore the typical red Turkish cap with a coat and sarong during colonial times. However, when national figures popularized black suits and caps during the independence era, some Hadhrami figures also began to replace them with black caps (songkok).

Today, the jubah and gamis are not everyday clothing of the Hadhrami. They are dressed just like other Indonesians. However, during religious rituals such as Friday prayers or other religious events, such as the maulid, men usually wear a sarong with a white baju koko and a typical Yemeni white or green cap. The Hadhrami women's clothing shows a more distinctive blend of things, a batik cloth with a kebaya top, and a headscarf (See Fig. 2). However, today, only elderly Hadhrami wear the kebaya. As for the younger women prefer to wear the headscarf and a loose-fitting dress, while some choose to wear the niqab.

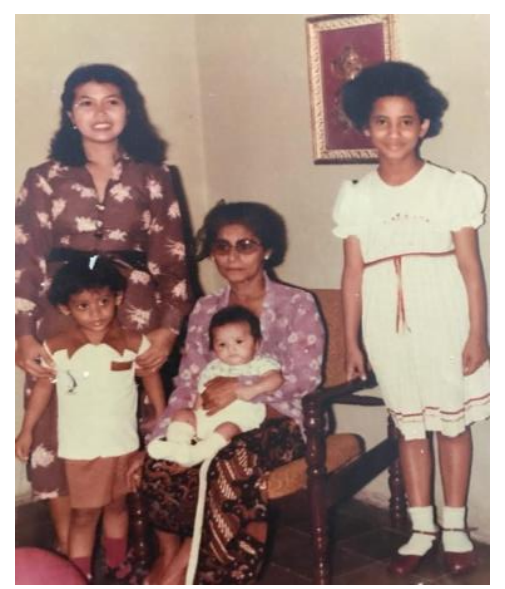

Figure 2. Photo of Hadhrami women from the family of Al-Aydrus wore a kebaya, jarik, complete with a bun (Source: Abu Bakr Al-Aydrus Private Collection) [41].

Looking Looking at Semarang wedding outfits, one can see a powerful Arab influence. This can be seen from using the jubah and gamis for the groom, complete with a headband (Imamah) turban decorated with flowers. Meanwhile, the bride wore a dress with a head covering. Such wedding outfits can still be found among Hadhrami families who live in Kampung Kauman, Semarang. Hadhrami Semarangan weddings are usually held around the maulid (reading the history of the prophet, one of the Hadhrami traditions) ceremonies. As is the case with the traditions in Hadhramaut, the wedding ceremony is attended by the groom with all-male guests. Meanwhile, the bride and groom are in separate places.

However, some Hadhrami is more flexible and willing to hold wedding ceremonies in Javanese customs. As the capital of Central Java, Semarang is closely related to the Javanese culture of Surakarta. Therefore, the marriage customs follow those of Surakarta and not Yogyakarta. This is apparent in the wedding dress procession (See Fig. 3). Instead of playing qasidah and gambus (Arabic music), some Hadhrami families used Javanese klenengan at weddings. The younger Hadhrami generation, however, prefers more straightforward weddings. As Arabic music grew in popularity, weddings with a more Arab 
atmosphere have become an option. Of course, this cannot be separated from opening a more varied and modern wedding organizer service business.

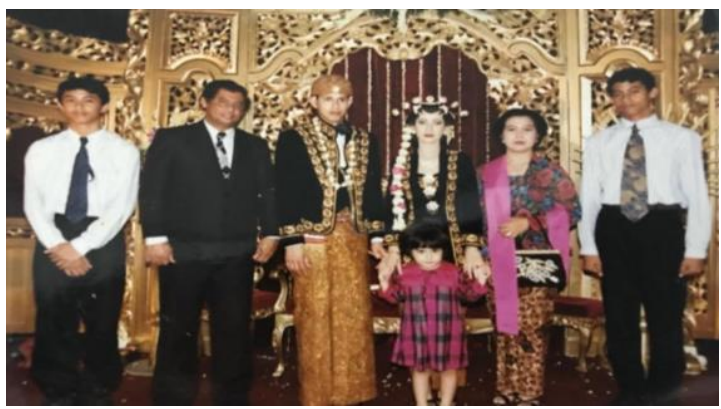

Fig. 3. Photo of a wedding of the Hadhrami from the family of Sungkar in Javanese customs (Source: Abu Bakar Al-Aydrus Private Collection) [42].

\subsubsection{Food}

"As Indonesian Muslims, we should know how to plant coconut trees, and not date palms" [43].

The above remark signifies the contrast of the Hadhramis' lives in Indonesia to those of their ancestors in Hadhramaut. If date palms evoke images of the desert and the Middle East, coconut trees provide a picture of the tropical environment of the Indonesian archipelago. The analogy above becomes appropriate in the context of food due to cultural encounters between the Hadhrami people and Javanese culture. As is the case with Javanese society, almost all cultural and social activities of the Hadhrami people involve food. Therefore, the influence of Javanese culture is visible in the food of the Hadhrami.

In the many Hadhrami specialities, kebuli rice is the most popular in the community. Nasi kebuli is a rice dish with a savoury flavour. This rice is cooked with lamb broth, goat's milk, and ghee. Kebuli rice is served with mutton and sprinkled with sliced dates and raisins. In Indonesia, goat's milk is usually replaced with coconut milk (santan), while mutton is sometimes mixed in rice, sometimes fried and served separately (See Fig. 4) [44]. There is also a version of kebuli rice with beef cooked in rendang, but originally cooked without santan. Spices mashed and sauteed with rice are garlic, shallots, black pepper, cloves, coriander, cumin, cardamom, cinnamon, and nutmeg. Kebuli rice is usually served with pickled pineapple or fried liver sauce (sambal goreng ati). Among these ingredients, coconut milk and fried liver with chili paste (sambal goreng ati) may be called a Javanese flavour influence. Coconut milk, which is extracted from coconut flesh, is commonly found in Indonesia. Its savoury taste can replace the savoury goat's milk which may not suit many Indonesians' palates.

Meanwhile, fried liver with chilli paste is usually served to accompany lontong opor, or rice cake curry, which are not only popular in Semarang. In nearly all areas settled by the Hadhrami, such dishes are popular. In addition, instead of kebuli rice, several Hadhrami families in Semarang also serve noodles and Javanese tumpeng in birthday ceremonies and other celebrations. 


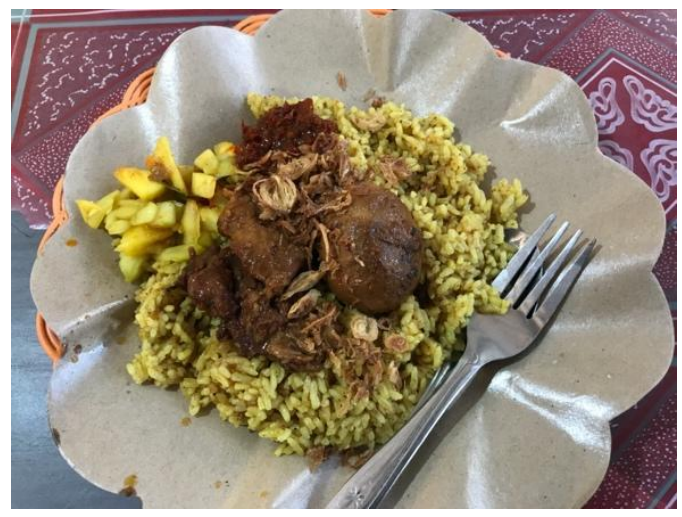

Fig. 4. Photo of nasi kebuli with beef, sambel, pickled pineapple, and bacem eggs typical of Nasi Kebuli Ibu Aminah, Jalan Petek 76, Semarang (Source: Photo by Rabith Jihan Amaruli) [45].

\section{Conclusion}

The cultural encounter between the Hadhrami community and Javanese culture resulted from their migration in the late 19th century. From Hadhramaut, the land of origin of the Hadhrami, they travelled across the Indian Ocean and settled in new places in the archipelago. One of the Hadhrami diaspora centres is Semarang, an important port city on the north coast of Java. In Semarang, they have adapted while maintaining their Hadhrami cultural identity. In the 20th century, the integration of the Hadhrami to Javanese culture became stronger, as shown the willingness of younger Hadhrami to adopt local customs in Semarang.

The secret to the success of the Hadhrami diaspora in their new homeland is the degree of their adaptation to Javanese culture. This article proves how the integration of Javanese culture with the life of the Hadhrami people in Semarang has formed a hybrid Hadhrami culture, as seen in language, fashion, and food. Even though they lived together and connected with the Chinese, the influence of Javanese culture on Hadhrami was felt stronger. This is believed to be caused by religious factors. As a coastal city with an egalitarian and cosmopolitan character, Semarang has contributed to the success of the cultural integration of the Hadhrami.

\section{Acknowledgements}

The authors would like to thank the Directorate of Higher Education Ministry of Education and Culture Republic of Indonesia under Research for Doctoral Dissertation Program (2021).

\section{References}

1. Sulistiyono, Singgih Tri and Y. Rochwulaningsih, "Contest for hegemony: The dynamics of inland and maritime cultures relations in the history of Java island, Indonesia," J. Mar. Isl. Cult., vol. 2, no. 2, p. 115-127, Desember 2013, doi: https://doi.org/10.1016/j.imic.2013.10.002, p. 126.

2. H. de Jonge, "Dutch Colonial Policy Pertaining to Hadhrami Immigrants," in Hadhrami Traders, Scholars and Statesmen in the Indian Ocean, 1750s-1960s, Leiden-New YorkKoln: Brill, 1997, p. 94.

3. "Koloniaal Verslag, 1860-1907." 
4. V. den Berg, Orang Arab di Nusantara. Jakarta: Komunitas Bambu, 2010, p. 95, 191 203, 132, 106, 169.

5. L. B. Christiansen, L. P. Galal, and K. Hvenegaard-Lassen, "Organised Cultural Encounters: Interculturality and Transformative Practices," J. Intercult. Stud., vol. 38, no. 6, p. 599, 2017, doi: https://doi.org/10.1080/07256868.2017.1386636.

6. M. M. Kraidy, Hybridity, or the Cultural Logic of Globalization. Philadelphia: Temple University Press, 2005.

7. M. M. A. Bin Sumait, H. A. H. AL-Aidaros, and M. A. S. Bladram, "The Impact of Indonesian Culture on Hadhrami Community (Language- Cuisine - Dress Architecture)," Int. J. Sci. Technol. Res., vol. 9, no. 4, p. 1788, Apr. 2020.

8. H. de Jonge and N. Kaptein, Transcending Borders: Arabs, Politics, Trade, and Islam in Southeast Asia. Leiden: KITLV, 2002.

9. A. I. Abushouk and H. A. Ibrahim, The Hadhrami Diaspora in Southeast Asia Identity Maintenance or Assimilation? Leiden-Boston: Brill, 2009.

10. L. Manger, The Hadrami Diaspora Community-Building on the Indian Ocean Rim. New York: Berghans Book, 2010.

11. L. Gottschalk, Mengerti Sejarah. Jakarta: UI Press, 2003.

12. G. Garraghan, A Guide to Historical Method. New York: Fordham University Press, 1957.

13. G. J. Renier, Metode dan Manfaat Ilmu Sejarah. Yogyakarta: Pustaka Pelajar, 1997.

14. Kuntowijoyo, Pengantar Ilmu Sejarah. Yogyakarta: Yayasan Bentang Budaya, 1995.

15. J. Heiss and M. Slama, "Genealogical Avenues, Long-Distance Flows and Social Hierarchy Hadramī Migrants in the Indonesian Diaspora," Anthropol. Middle East, vol. 5, no. 1, pp. 34-52, 2010, doi: 10.3167/ame.2010.050104.

16. E. Ho, "Genealogical Figures in an Arabian Indian Diaspora," University of Chicago, Chicago, 2000.

17. C. Lekon, "The Impact of Remittances on the Economy of Hadhramaut, 1914-1967," in Hadhrami Traders, Scholars, and Statesmen in the Indian Ocean, 1750s-1960s, LeidenNew York-Koln: Brill, 1997, p. 265.

18. W. G. Clarence-Smith, "Hadhrami Enterpreneurs in the Malay Word, c.1750 to c.1940," in Hadhrami Traders, Scholars and Statesmen in the Indian Ocean, 1750s-1960s, LeidenNew York-Koln: Brill, 1997, p. 267, 305.

19. A. Mahsun, May 26, 2021.

20. Regerings Almanak van Nederlansch-Indië 1898.

21. F. F. Jacobsen, Hadrami Arabs in Present-day Indonesia An Indonesian-Oriented group with an Arab signature. London and New York: Routledge, 2009.

22. F. F. Jacobsen, "Marriage Patterns and Social Stratification in Present Hadrami Arab Societies in Central and Eastern Indonesia," Asian J. Soc. Sci., vol. 35, pp. 472-487, 2007, doi: 10.1163/156853107X240305, p. 477.

23. A. S. Bujra, "Political Conflict and Stratification in Hadramaut I," Middle East. Stud., vol. 3, no. 4, p. 355-375, Jul. 1967, p. 364.

24. L. Boxberger, On the Edge of Empire Hadramawt, Emigration, and the indian Ocean, 1880s-1930s. New York: University of New York Press, 2002.

25. M. Slama, "Marriage Crisis Revisiting a Mayor Dispute Among Hadhramis in Indonesia," Camb. Anthropol., vol. 32, no. 2, pp. 65-80, 2014, doi: 10.31 67/CO.201 4.3202, p. 67-68. 
26. H. de Jonge, "Discord and Solidarity among the Arabs in the Netherlands East Indies, 1900-1942," Indonesia, vol. 55, pp. 73-90, 1993, p. 81.

27. H. de Jonge, "Abdul Rahman Baswedan and the Emancipation of the Hadramis in Indonesia," Asian J. Soc. Sci., vol. 32, no. 3, pp. 373-400, 2004, p. 386-387, 390, 393.

28. Dyah, Dec. 20, 2020.

29. U. Daniel, Feb. 07, 2021.

30. R. J. Amaruli, "Hadrami Diaspora in Karimunjawa: Between Identity Maintenance and Assimilation," Humanika, vol. 19, no. 1, 2014, p. 140.

31. “https://wiki.laduni.id/ Habib_Zein_bin_Ali_bin_Ahmad_bin_Umar_Al_Jufri," Apr. 21, 2021.

32. D. Susanto, "Pola Strategi Dakwah Komunitas Habaib di Kampung Melayu Semarang," Dimas, vol. 14, no. 1, pp. 159-185, 2014, p. 181-182.

33. A. B. Alaydrus, Apr. 24, 2021.

34. T. Suliyati, Apr. 24, 2021.

35. Ali, Apr. 20, 2020.

36. "https://www.youtube.com/watch?v=zZEYhdl8vw0," Apr. 25, 2021.

37. R. J. Amaruli, "Photo of the tomb of Habib Achmad bin Muhammad bin Ali As-Segaf (died 8 April 1976), a figure of the Semarang Hadhrami in the cemetery of the As-Segaf Family, Bergota Semarang," 2021.

38. "http://unissula.ac.id/c24-berita-unissula/ hasan-toha-pimpin-y Yayasan-unissula/," Apr. 24, 2021.

39. “https://hidayatullahsemarang.com/profil-lpi-hidayatullah/," Apr. 24, 2021.

40. I. F. Alatas, "Menjadi Arab: Komunitas Hadrami, Ilmu Pengetahuan Kolonial \& Etnisitas," in Orang Arab di Nusantara, Jakarta: Komunitas Bambu, 2010, p. xxxiv.

41. A. B. Alaydrus, "Photo of Hadhrami women from the family of Al-Aydrus wore a kebaya, jarik, complete with a bun," c.1980s.

42. A. B. Alaydrus, "Photo of a wedding of the Hadhrami from the family of Sungkar in Javanese customs," c.2000s.

43. I. F. Alatas, "Aligning the Sunna and the Jama'a: Religious Authority and Islamic Social Formation in Contemporary Central Java, Indonesia," University of Michigan, Michigan, 2016, p. 1.

44. Aminah, May 26, 2021.

45. "Photo of nasi kebuli with beef, sambel, pickled pineapple, and bacem eggs typical of Nasi Kebuli Ibu Aminah, Jalan Petek 76, Semarang. Photo by Rabith Jihan Amaruli, 2021." 